\title{
PENINGKATAN KEPUASAN MAHASISWA MELALUI KUALITAS PELAYANAN AKADEMIK (STUDI KASUS PADA FAKULTAS KEGURUAN DAN ILMU PENDIDIKAN UNIVERSITAS ISLAM AS-SYAFI'IYAH JAKARTA)
}

\author{
Fahmi Kamal $^{1 *}$, Widi Winarso ${ }^{2}$, Lia Mardiani ${ }^{3}$ \\ Fakultas Ekonomi dan Bisnis, Universitas Bina Sarana Informatika \\ $\underline{\text { fahmi.fmk@bsi.ac.id1 }}{ }^{1}, \underline{\text { widi.winarso@dsn.ubharajaya.ac.id }}{ }^{2}, \underline{\text { lia966281@gmail.com }}^{3}$
}

\begin{abstract}
Abstrak
Kualitas Pelayanan yang baik dapat dijadikan sebagai salah satu strategi pesaing usaha dalam pendekatan dengan pelanggan. Tujuan penelitian mengetahui seberapa besar Pengaruh Kualitas Pelayanan Akademik Terhadap Kepuasan Mahasiswa Pada Fakultas Keguruan dan Ilmu Pendidikan Universitas Islam AsSyafi'iyah Jakarta. Penelitian ini merupakan metodologi penelitian deskriptif kuantitatif dengan perhitungan data menggunakan SPSS versi 22.0. Populasi yang diambil adalah rata-rata pelayanan dan kepuasan. Sampel dari 100 Mahasiswa dalam penelitian ini adalah 40 (empat puluh) Mahasiswa yang datang ke FKIP UIA. Instrumen penelitian ini menggunakan kuesioner dengan jumlah 20 (dua puluh) butir pernyataan dan analisis ini menggunakan metode pengumpulan data uji koefisien korelasi, uji koefisien determinasi dan uji persamaan regresi. Hasil penelitian ini menunjukan bahwa kualitas pelayanan memiliki pengaruh terhadap 80,4\% terhadap kepuasan sisanya sebesar 19,6\% dipengaruhi faktor lain yang diteliti. Kinerja, karakteristik operasi pokok dari produk inti (core product) yang dibeli, keistimewaan tambahan, Keandalan (reliability), Kesesuaian dengan spesifikasi, Daya tahan, Serviceability, Estetika dan kualitas yang dipersepsikan. Dari tingkat rumusan masalah apakah terdapat pengaruh kualitas pelayanan dan kepuasan mahasiswa di FKIP UIA,seberapa besar pengaruh kualitas Pelayanan dan kepuasan mahasiswa di FKIP UIA,seberapa persen pengaruh kualitas Pelayanan dan Kepuasan Mahasiswa di FKIP UIA, hubungan kualitas pelayanan dengan kepuasan mahasiswa menunjukan hasil yang sangat kuat, dilihat dari perhitungan koefisien korelasi sebesar 0,896 , serta hasil persamaan regresi $\mathrm{Y}=4,495+0,932 \mathrm{X}$ menunjukan baik dengan konstanta a sebesar 4,495 dan konstanta b sebesar 0,932 adalah positif dan searah serta dapat disimpulkan bahwa terdapat persamaan hasil yang signifikan. Penilaian responden terhadap pelayanan di FKIP UIA sangat kuat 80,4\% namun perlu ditingkatkan lagi pelayanannya. Mengingat pentingnya pelayanan sesuai dengan aturan yang ada.
\end{abstract}

Kata Kunci : Kualitas Pelayanan, Kepuasan Pelanggan.

\begin{abstract}
Good service quality can be used as a strategy in approaching customers. If the customer feels comfortable with the services provided, the customer is indirectly satisfied. The research objective was to find out how much the influence of academic service quality on student satisfaction at the Teacher Training and Education Faculty of As-Syafi'iyah Islamic University, Jakarta. This research is a quantitative approach with the calculation of data using SPSS version 22.0. The population taken is the average service and satisfaction. The sample in this study were forty (40) students who came to FKIP UIA. The instrument of this study uses a questionnaire with a number of twenty (20) items statement and analysis using the correlation coefficient test, test the coefficient of determination and regression equation test. The results of this study indicate that service quality has an influence on $80.4 \%$ of satisfaction and the remaining $19.6 \%$ is influenced by other factors studied, for example facilities and others. From the level of relationship quality of service with student satisfaction shows very strong results, seen from the calculation of the correlation coefficient of 0,896 , and the results of the regression equation $Y=4,495+0,932 X$ shows good with a constant of 4,495 and constant $b$ of 0,932 positive and it can be concluded that there are significant equations. Respondents' assessment of the services at the Faculty of Teacher Training and Education at the Islamic University of Asyafiyah is quite good but needs to be improved again. Given the importance of service in accordance with existing rules.
\end{abstract}

Keywords : Service Quality, Customer Satisfaction 


\section{PENDAHULUAN}

Era globalisasi saat ini, kualitas pelayanan di pandang sebagai salah satu indikator untuk mencapai keunggulan kompetitif, karena kualitas pelayanan merupakan salah satu faktor yang menentukan pemilihan sesuatu yang dapat memuaskan mahasiswa. Kepuasan mahasiswa akan tercapai apabila kualitas jasa yang diberikan sesuai kebutuhannya. Kualitas pelayanan merupakan tingkat keunggulan yang diharapkan dan pengendalian atas tingkat keunggulan untuk memenuhi keinginan mahasiswa.

Perubahan global yang sangat cepat mendorong perguruan tinggi untuk terus beradaptasi dan memperbarui diri. Pendidikan tinggi di Indonesia masih mengalami banyak tantangan mulai dari daya saing, kualifikasi, dan kompetensi dosen, peningkatan infrastruktur pendidikan, dan kesiapan teknologi. Banyak cara yang bisa dilakukan untuk mendorong kualitas perguruan tinggi menjadi lebih unggul. Salah satunya riset dengan kolaborasi bersama perguruan tinggi berkelas dunia. Menurut Kementerian Riset, Teknologi dan Pendidikan Tinggi, bahwa tantangan revolusi industri harus direspon secara cepat dan tepat oleh seluruh yang berkepentingan.

Revolusi industri 4.0 mulai merambah kebidang pendidikan khususnya pendidikan tinggi. Banyak perguruan tinggi dengan adanya revolusi industri 4.0 berlomba-lomba memberikan pelayanan yang terbaik berbasis teknologi informasi. Saat ini teknologi informasi telah menjadi bagian yang tidak terpisahkan dalam pengelolaan pendidikan tinggi. Manfaat yang di rasakan oleh konsumen pendidikan tinggi (mahasiswa) terhadap pelayanan berbasis teknologi informasi memudahkan mahasiswa untuk mengelola sendiri perkuliahan yang akan di tempuhnya. Ini menandakan bahwa pelayanan terhadap mahasiswa berbasis teknologi informasi akan meningkatkan kepuasan mahasiswa dalam menempuh pendidikan di perguruan tinggi.

Fakultas Keguruan dan Ilmu Pendidikan merupakan salah satu fakultas yang berada di Universitas Islam As-syafi'iyah. Fakultas ini memiliki dua program studi berbasis Bahasa Inggris (BI) dan program studi berbasis Bimbingan Konseling (BK). Fakultas Keguruan Ilmu dan Pendidikan tengah berbenah untuk menjadikan pelayanan yang telah diberikan kepada mahasiswa menjadi lebih baik kedepannya.

\section{Rumusan Masalah}

Dalam penulisan ini penulis fokus pada variabel yang mempengaruhi kepuasan mahasiswa yaitu kualitas pelayanan akademik. Sehingga berdasarkan latar belakang dan identifikasi masalah yang telah diuraikan diatas, maka dapat dirumuskan masalah penulisan sebagai berikut:

1. Apakah kualitas pelayanan akademik berpengaruh terhadap kepuasan mahasiswa Pada Fakultas Keguruan Dan Ilmu Pendidikan Universitas Islam As-Syafi'iyah Jakarta?

2. Berapa besar pengaruh kualitas pelayanan dan kepuasan Mahasiswa di Fakultas Keguruan dan Ilmu Pendidikan Universitas Islam Assyafi'iyah?

\section{Tujuan Penulisan}

Tujuan penulisan ini adalah untuk mengetahui dan menjelaskan secara ilmiah pengaruh kualitas pelayanan akademik terhadap kepuasan mahasiswa Pada Fakultas Keguruan Dan Ilmu Pendidikan Universitas Islam As-Syafi'iyah Jakarta. Sesuai dengan maksud penulisan tersebut, maka tujuan penulisan ini adalah :

1. Untuk mengetahui dan menjelaskan kuat pengaruh kualitas pelayanan akademik terhadap kepuasan mahasiswa Pada Fakultas Keguruan Dan Ilmu Pendidikan Universitas Islam AsSyafi'iyah Jakarta..

2. Untuk mengetahui seberapa besar pengaruh kualitas pelayanan dan kepuasan mahasiswa Fakultas Keguruan dan Ilmu Pendidikan Universitas Islam As-Syafi'iyah Jakarta.

\section{TINJAUAN PUSTAKA}

\section{Kualitas Pelayanan}

Kualitas didefinisikan dengan penggambaran karakteristik langsung dari suatu produk, seperti performansi, keandalan, kemudahan dalam penggunaan, estetika dan sebagainya. Dalam era globalisasi, secara strategik kualitas didefinisikan sebagai segala sesuatu yang mampu memenuhi keinginan atau kebutuhan pelanggan (meeting the needs of customers). Keunggulan suatu produk terukur melalui tingkat kepuasan pelanggan. Karakteristik sistem kualitas modern dicirikan dalam lima aspek, yaitu: berorientasi pada pelanggan, adanya partisipasi aktif yang dipimpin oleh manajemen puncak, adanya pemahaman dari setiap orang terhadap tanggung jawab spesifik untuk berkualitas, adanya aktivitas yang berorientasi pada tindakan pencegahan kerusakan 
dan adanya suatu filosofi yang menganggap bahwa kualitas merupakan jalan hidup (way of life) (Ariani, 2016).

Atmaja (2018:11) menyatakan bahwa, "Kualitas merupakan suatu kondisi dinamis yang berpengaruh dengan produk, jasa, manusia, proses dan lingkungan yang menemui atau melebihi harapan.”

Kotler,dkk dalam Suryati,(2015:23)" Kualitas adalah keseluruhan corak dan karakteristik dalam sebuah produk atau jasa yang menunjang kemampuan untuk memuaskan pelanggan baik secara langung maupun tidak langsung".

Kesimpulan dari teori diatas dapat didefinisikan bahwa kualitas merupakan suatu kondisi yang berpengaruh pada produk maupun jasa yang mendukung untuk memberikan kepuasan baik secara langsung maupun tidak langsung.

Perusahaan yang maju adalah perusahaan yang senantiasa memberikan kualitas atas barang atau jasa yang dijualnya. Kualitas menjadi satu modal utama perusahaan dalam memasarkan produknya kepada publik. Dengan kualitas yang baik akan memberikan kesan kepada publik untuk menumbuhkan kepuasan terhadap pelanggan (Fikri, Wiyani, \& Suwandaru, 2016) Tujuan dilakukan penelitian ini adalah untuk mengetahui seberapa besar pengaruh variabel kualitas pelayanan dalam mempengaruhi kepuasan mahasiswa. Menurut Daryanto dan setyobudi (2014:135) Pelayanan adalah suatu kumpulan atau kesatuan yang melakukan kegiatan menguntungkan dan menawarkan suatu kepuasan meskipun hasilnya secara fisik tidak terikat kepada produk.

Menurut (Sediawan, 2015) berpendapat bahwa "pelayanan adalah suatu bentuk sistem, prosedur atau metode tertentu yangdiberikan kepada orang lain dalam hal ini konsumen agar kebutuhan konsumen tersebut dapat terpenuhi sesuai dengan harapan mereka.

"Kualitas pelayanan (service quality) telah hampir menjadi faktor yang menetukan dalam menjaga keberlangsungan suatu organisasi birokrasi pemerintah maupun organisasi perusahaan".(Sugeng, I. S., \& Rafik, 2018).

Kualitas pelayanan yang baik dan sesuai dengan kebutuhan pengguna jasa publik, sangat penting dalam upaya mewujudkan kepuasan pengguna jasa publik (customer satisfaction)".(Sugeng, I. S., \& Rafik, 2018).

Menurut Tjiptono menyimpulkan bahwa : "Kualitas pelayanan adalah tingkat keunggulan yang diharapkan dan pengendalian atas tingkat keunggulan tersebut untuk memenuhi keinginan pelanggan sedangkan kepuasan pelanggan adalah tingkat perasaan seseorang setelah membandingkan kinerja atau hasil yang dirasakannya dengan harapannya".(Sugeng, I. S., \& Rafik, 2018).

Goetsch and Davis dalam (Sugiyono, 2014:320) memberikan definisi tentang kualitas adalah sebagai berikut, "Quality is dynamic state associate with product, service, people, process, and environments that meets or exceeds, expectations". (Sugeng, I. S., \& Rafik, 2018) "Kualitas merupakan pernyataan yang dinamis yang terkait dengan produk, pelayanan, orang, proses, dan lingkungan yang dapat memenuhi atau melebihi yang diharapkan". Menurut Mukarom, Zaenal (2015:6) Secara teoritis, tujuan pelayanan publik pada dasarnya adalah memuaskan masyarakat. Untuk mrncapai kepuasan itu dituntut Kualitas peayanan publik yang tercermin dari:

1. Transparasi, yakni pelayanan yang bersifat terbuka, mudah dan dapat semua pihak yang membutuhkan dan disediakan secara memadai serta mudah dimengerti.

2. Akuntabilitas, yakni pelayanan yang dapat dipertanggungjawabkan sesuai dengan ketentuan peraturan perundang-undangan.

3. Kondisional, yakni pelayanan yang sesuai dengan kondisi dan kemampuan pemberi dan penerima pelayanan dengan tetap berpegang pada prinsip efisiensi dan efektivitas.

4. Pastisipatif, yakni pelayanan yang dapat mendorong peran serta masyarakat dalam penyelenggaraan pelayanan publik dengan memperhatikan aspirasi,kebutuhan, dan harapan masyarakat Kesamaan hak, yaitu pelayanan yang tidak melakukan diskriminasi dilihat dari aspek apapun khususnya suku, ras, agama, golongan, status sosial, dan lain-lain.

5. Keseimbangan hak dan kewajiban, yaitu pelayanan yang mempertimbangkan aspek keadilan antara pemberi dan penerima pelayanan public.

\section{Dimensi Kualitas Pelayanan}

Zeithaml dkk dalam Mardo, (2016:31) Memberikan indikator ukuran kualitas pelayanan yang terletak pada 5 (lima) dimensi, yaitu:

1. Tangibles (kualitas pelayanan yang berupa sarana fisik perkantoran, komputerisasi administrasi, ruang tunggu, tempat informasi dan sebagainya);

2. Reliability (Kemampuan dan keandalan unuk menyediakan pelayanan yang terpercaya);

3. Responsiveness (Kesanggupan untuk membantu menyediakan pelayanan secara cepat dan tepat, serta tanggap terhadap keinginan pelanggan); 
4. Assurance (Kemampuan dan Kramahan, serta sopan santun pegawai dalam meyakinkan kepercayaan pelanggan);

5. Emphaty (Sikap tegas tetapi perhatian dari pegawai terhadap pelanggan)

Menurut Wijaya, (2018:10) Ada delapan dimensi kualitas, yaitu:

1. Kinerja/Performance, yaitu tingkat konsistensi dan kebaikan fungsi-fungsi produk.

2. Keindahan/Aesthetics. Estetika berhubungan dengan penampilan wujud produk (misalnya, gaya dan keindahan) serta penampilan fasilitas, peralatan, personalia, dan materi komunikasi yang berkaitan dengan jasa.

3. Kemudahan perawatan dan perbaikan/ Serviceability. Berkaitan dengan tingkat kemudahan merawat dan memperbaiki produk.

4. Keunikan/Features, yaitu karakteristik produk yang berbeda secara fungsional dari produkproduk sejenis. Misalnya fungsi mobil adalah untuk alat transportasi. Namun, suatu mobil mungkin dilengkapi dengan mesin empat silinder, transmisi manual, pembungkus tempat duduk, tempat duduk untuk empat penumpang, dan rem cakram roda depan; sementara mobil yang lainnya dilengkapi dengan mesin enam silinder, transmisi otomatis, tempat duduk kulit, tempat duduk untuk enam penumpang, dan rem anti kejut.

5. Reliabilitas. Reliabilitas adalah probabilitas produk atau jasa menjalankan fungsi yang dimaksud dalam jangka waktu tertentu.

6. Daya tahan/Durability. Didefinisikan sebagai umur manfaat dari fungsi produk.

7. Kualitas Kesesuaian/Quality of Comformanc, yaitu ukuran mengenai apakah sebuah produk atau jasa telah memenuhi spesifikasi yang telah ditetapkan.

8. Kegunaan yang sesuai/ Fitness for use, yaitu kecocokan produk menjalankan fungsi-fungsi sebagaimana yang diiklankan atau dijanjikannya.

Dari dua definisi diatas dapat disimpulkan bahwa kualitas pelayanan merupakan faktor penting yang dapat menentukan keberlangsungan suatu organisasi. Melalui kualitas pelayanan dapat terlihat kepuasan yang tercapai sesuai dengan kebutuhannya masyarakat tersebut.

\section{Karakteristik Jasa/Pelayanan}

Menurut Kotler yang dikutip kembali oleh Fandy Tjijptono (2014), secara garis besar karakteristik jasa terdiri dari intangibility, inseparability, variability/ heterogeneity, perishability dan lack of ownership.
1. Intangibility. Jasa berbeda dengan barang. Bila barang merupakan suatu objek, alat atau benda maka jasa adalah suatu perbuatan, tindakan, pengalaman, proses, kinerja (performance) atau usaha. Oleh karena itu jasa tidak dapat dilihat, dirasa, dicium, didengar atau diraba sebelum dibeli dan dikonsumsi.

2. Inseparability. Barang biasanya diproduksi kemudian dijual lalu dikonsumsi. Sedangkan jasa umumnya dijual terlebih dahulu, baru diproduksi dan dikonsumsi pada waktu dan tempat yang sama.

3. Heterogeneity/variability/inconsistency. Jasa bersifat sangat variabel karena merupakan nonstandardized output, artinya terdapat banyak variasi bentuk,kualitas dan jenis,tergantung pada siapa, kapan, dan dimana jasa tersebut diproduksi.

4. Perishability. Perishability berarti jasa tidak dapat disimpan dan tidak tahan lama

5. Lack of Ownership. Merupakan perbedaan dasar antara barang dan jasa. Pada pembelian barang konsumen memiliki hak penuh atas penggunaan dan manfaat produk yang dibelinya. Mereka dapat mengkonsumsi, menyimpang atau menjualnya. Di lain pihak, pada pembelian jasa, pelanggan hanya akan memiliki akses personal dan dengan jangka waktu yang.

\section{Keterampilan Dasar Pelayanan}

Keterampilan dasar yang dapat diterapkan dalam semua strategi pelayanan menurut Daryanto dan Ismanto (2014:77), yaitu:

1. Pusatkan perhatian pada pelanggan

Cara yang dapat ditempuh adalah mendengarkan dengan penuh perhatian dan jangan sekali-kali memotong pembicaraan selain itu, menanggapi pembicaraan pelanggan apabila pelanggan mengharapkan tanggapan anda.

2. Memberikan pelayanan yang efisien Cara yang dapat dilakukan adalah melayani pelanggan berikutnya segera setelah selesai dengan pelanggan pertama, merencanakan apa yang selanjutnya akan dilakukan dan menindaklanjuti pelayanan sampai tuntas.

3. Meningkatkan perasaan harga diri pelanggan Cara yang dapat dilakukan adalah mengenali kehadiran pelanggan dengan segera, tidak menggurui pelanggan, bagaimanapun pintarnya anda dan memuji dengan tulus serta memberikan penghargaan kepada pelanggan

4. Membina hubungan baik dengan pelanggan Cara yang dapat dilakukan adalah mendengarkan apa yang disampaikan oleh pelanggan tanpa memotong pembicaraannya dan 
menunjukkan simpati dan berbicara dengan penuh perasaan, untuk menunjukkan bahwa anda mengerti dan memahami perasaan pelanggan.

5. Dapat menentukan keinginan pelanggan

Cara yang dilakukan adalah menanyakan kepada pelanggan dan mengulangi kembali apa keinginan pelanggan, kemudian menarik inti dari apa yang dikatakan.

6. Mengalihkan pelayanan ke orang lain

Cara yang dilakukan adalah bila seorang pelanggan meminta pelayanan di luar kemampuan anda, cara terbaik adalah mengalihkan pelayanan tersebut kepada orang lain yang lebih mampu.

\section{Unsur - unsur Pelayanan}

Barata (2014:11) terdapat empat unsur penting dalam proses pelayanan untuk mencapai tujuan suatu perusahaan atau instansi dalam memberikan kualitas pelayanan, yaitu:

1. Penyediaan layanan yaitu pihak dapat memberikan suatu layanan tertentu kepada konsumen, baik berupa layanan dalam bentuk penyediaan dan penyerahaan barang $(\mathrm{good})$ atau jasa-jasa (service).

2. Peneriman layanan, yaitu mereka yang disebut konsumen (customer) atau customer yang menerima berbagai layanan dari penyedian layanan kepada pihak yang membutuhkan layanan.

3. Jenis layanan, yaitu layanan yang dapat diberikan oleh penyedian layanan kepada pihak yang membutuhkan layanan.

4. Kepuasan pelanggan, dalam memberikan layanan penyediaan layanan harus mengacu pada tujuan utama pelayanan, yaitu kepuasaan pelanggan hal ini sangat penting dilakukan karena tingkat kepuasan yang diperoleh para pelanggan itu biasanya sangat berkualitas erat dengan standar kualitas barang dan atau jasa yang mereka nikmati.

\section{Kepuasan Pelanggan}

Kepuasan pelanggan adalah tingkat perasaan seseorang setelah membandingkan kinerja yang ia rasakan dibandingkan harapan. Kepuasan pelanggan adalah respon pelanggan terhadap evaluasi ketidaksesuaian yang dirasakan antara harapan sebelumnya dan kinerja aktual yang dirasakan setelah pemakaian. (Negeri et al., 2015). Menurut (Freddy Rangkuti, 2016) Kepuasan pelanggan selalu menjadi topik hangat di kalangan pebisnis, khususnya para pemasar, karena hal itu sangat menentukan tingkat pertumbuhan suatu usaha. Masalahnya jelas: bila pelanggan tidak puas, mereka akan berpaling kepada perusahaan lain. Masalahnya tidak berhenti di situ. Mereka cenderung menceritakan kekecewaan mereka kepada sanak saudara dan teman-teman mereka, malah ada yang mengirimkan surat tertulis ke media massa atau ke mailing-list sehingga masalah itu tersebar ke mana-mana dan sulit dihentikan. Akibatnya, nama perusahaan menjadi buruk di mata konsumen dan mereka yang belum mengenal perusahaan itu cenderung untuk tidak "berurusan" dengan perusahaan tersebut. Sekalipun sangat penting, banyak perusahaan sangat kesulitan untuk melihat dan mengukur sejauh mana pelanggan mereka tidak puas, kurang puas, puas, atau sangat puas terhadap produk atau jasa yang mereka tawarkan. Hal itu sulit ditentukan karena kepuasan (pelanggan) memang sangat subjektif: tergantung individu, mood ketika membeli, selera yang gampang berubah, dll. Di samping itu, tiap orang pasti mempunyai ekspektasi dan pengalaman yang berbeda terhadap produk atau jasa yang sama. Di dalam perusahaan pelanggan adalah hal yang penting, dengan adanya pelanggan perusahaan dapat berjalan dan berkembang. Menurut Lupiyoadi dalam (Windasuri, 2017:3)"pelanggan (customer) berarti orang yang secara kontinu dan berulang kali datang ke tempat yang sama untuk memuaskan keinginannya dengan memiliki suatu produk, atau mendapatkan suatu jasa dan memuaskan produk atau jasa tersebut".Menurut (Windasuri, 2017:3) mendifinisikan "pelanggan setiap orang, unit, atau pihak dengan siapa kita berinteraksi, baik langsung maupun tidak langsung, dalam penyediaan produk". Menurut (Setyabudi, 2014:49)"pelanggan adalah orang-orang yang kegiatannya membeli dan menggunakan suatu produk baik barang maupun jasa secara terus menerus".Dari beberapa kutipan diatas dapat disimpulkan bahwa pelanggan adalah setiap orang atau unit yang membeli dan menggunakan produk atau jasa yang dijual secara rutin.

Kata kepuasan atau satisfactionberasal dari bahasa latin "satis"(artinya cukup baik, memadai) dan "facio" (melakukan atau membuat). Secara sederhana kepuasan dapat diartikan sebagai upaya pemenuhan sesuatu atau membuat sesuatu memadai. Konsep kepuasan pelanggan masih bersifat abstrak, meski demikian kepuasan pelanggan menjadi konsep sentral dalam teori dan praktik pemasaran, serta merupakan salah satu tujuan esensial bagi aktivitas bisnis. Menurut (Richard F.Gerson, 2018) persepsi pelanggan bahwa harapannya telah terpenuhi atau terlampaui. Jika anda membeli suatu baran maka anda berharap 
barang tersebut akan berfungsi dengan baik, jika tidak anda tentu kecewa. Kotler dalam (Atmaja, 2018)"kepuasan pelanggan adalah perasaan senang atau kecewa seorang yang muncul setelah membandingkan antara kinerja (hasil) produk yang diperkirakan terhadap kinerja yang diharapkan". Berdasarkan (Windasuri, 2017: 64)"kepuasan pelanggan suatu tanggapan emosional pada evaluasi terhadap pengalaman komsumsi suatu produk atau jasa".Menurut Kotler, Philip, dan Garry Amstrong dalam (Windasuri, 2017: 64) mendefinisikan "kepuasan pelanggan sebagai tingkat perasaan seseorang setelah membandingkan kinerja (atau hasil) yang ia rasakan dengan harapannya".

Atmaja (2018:11) mengemukakan bahwa, "Kepuasan Mayarakat perasaan senang atau kecewa seseorang yang dihasilkan dari membandingkan kinerja atau hasil yang dirasakan produk atau layanan dengan harapan."

Suryati, (2015:93) "Kepuasan pelanggan adalah merupakan tingkat dimana suatu pencapaian performa dari sebuah produk yang diterima oleh pelanggan sama dengan ekspektasi pelanggan itu sendiri”.

Kotler dalam Kasmir (2017:236), "menyebutkan kepuasan pelanggan merupakan penilaian dari pelanggan atas penggunaan barang ataupun jasa dibandingkan dengan harapan sebelum penggunaannya"

Dari tiga definisi di atas dapat disimpulkan bahwa kepuasan masyarakat adalah perasaan atau tanggapan terhadap suatu barang atau jasa yang sesuai dengan harapan masyarakat. Dalam pelayanan jasa, kepuasan masyarakat diukur dengan tingkat kepuasan yang berdasarkan keseluruhan pengalaman dengan suatu perusahaan atau instansi tersebut.

\section{Faktor-Faktor Yang Mempengaruhi Kepuasan Pelanggan}

Menurut Tjiptono dalam Suryati, (2015:93) kepuasan pelanggan diukur dengan indikator yang terdiri dari delapan indikator yaitu kinerja (performance) karakteristik operasi pokok dari produk inti (core product) yang dibeli, keistimewaan tambahan (features), Keandalan (reliability), Kesesuaian dengan spesifikasi (conformace to specification), Daya tahan (durability), Serviceability, Estetika dan kualitas yang dipersepsikan (perceived quality).

Menurut Kasmir, (2017:240) Untuk mencapai tujuan pelanggan atau nasabah terus meningkat, maka perlu dilakukan atau didukung hal-hal sebagai berikut:
1. Memperhatikan Kualitas Pelayanan

Maksudnya, kualitas pelayanan dari karyawan yang melayani pelanggan dengan keramahan, sopan santun serta pelayanan cepat dan efisien. Karyawan disini maksudnya dimulai dari karyawan paling bawah sampai dengan pimpinan tertinggi di suatu perusahaan tersebut.

2. Faktor Pendekatan dan Kedekatan untuk Berinteraksi

Artinya, adanya interaksi yang baik antara pelanggan dengan karyawan tersebut. Dalam hal ini karyawan harus mampu memberlakukan pelanggan seperti teman lama, sehingga timbul keakraban dan kenyamanan selama berhubungan dengan perusahaan.

3. Faktor Harga yang Ditawarkan

Pengertian harga disini dibagi dua untuk perusahaan keunagan dan non keuangan. Untuk lembaga keuangan seperti bank adalah bunga, baik bunga simpanan, maupun bunga pinjaman atau bagi hasil dan biaya administrasi yang ditawarkan kompetitif dengan bank lain. Sedangkan untuk lembaga non keuangan adalah sejumlah uang yang harus dibayar pelanggan pada saat membeli produk.

4. Kenyamanan dan Keamanan Lokasi Perusahaan Artinya lokasi sebagai tempat dimana pelanggan berinteraksi. Dalam hal ini pelanggan selalu merasakan adanya kenyamanan baik di luar gedung maupun di dalam gedung. Pelanggan atau nasabah juga tidak merasa was-was bila berhubungan atau melakukan transaksi pembelian di perusahaan.

5. Penanganan Komplain atau Keluhan

Artinya, setiap ada keluhan atau komplain yang dilakukan pelanggan atau nasabah harus ditanggapi dan ditangani secara cepat dan tepat. Komplain atau keluhan merupakan salah satu bukti keteledoran atau kekurangan karyawan. Sebagai contoh misalnya komplain tentang lamanya waktu pelayanan, atau tentang sering macetnya peralatan yang digunakan. Komplain juga sering terjadi karena suasana ruangan yang tidak teratur, panas atau tidak nyaman. Lebih parah kalau komplain dikarenakan karyawan yang melayani melakukan berbagai kesalahan.

6. Kelengkapan dan Kegunaan Produk

Misalnya khusus untuk produk perusahaan lembaga keuangan harus tersedia fasilitas ATM di berbagai tempat lokasi-lokasi strategis. Termasuk kelengkapan fasilitas dan produk yang ditawarkan. Untuk semua perusahaan faktor kelengkapan jenis produk yang ditawarkan perlu memperoleh perhatian yang 
serius. Jangan sampai ada pelanggan yang menginginkan salah satu jenis produk akan tetapi tidak tersedia dan hal ini akan menjadi preseden yang tidak baik bagi karyawan maupun pelanggan.

7. Dan Hal Lainnya

Faktor-faktor diatas perlu dijalankan dengan sebaik-baiknya, sehingga kesempurnaan pelayanan menjadi lebih baik lagi. Memang ada praktiknya terkadang karyawan sudah menjalankan seluruh pekerjaan yang menjadi tanggung jawabnya, tetap saja ada kesalahan yang terjadi. Akan tetapi, jika karyawan sudah menjalankannya dengan sebaik-baiknya, maka kejadian yang tidak diinginkan dapat diminimalkan. Dengan menggunakan istilah tidak ada gading yang tak retak, maka pelayanan yang diberikan karyawan akan terus berjalan dengan sebaik-baiknya.

\section{Harapan Pelanggan}

Alma dalam (Sediawan, 2015) menyatakan pelanggan menginginkan layanan yang baik dengan harapan sebagai berikut:

1. Kualitas layanan yang konsisten

2. Sikap personil yang selalu ramah

3. Kejelasan suara, gambar, atau cetakan

4. Tidak terlalu sering gangguan, kerusakan, kalaupun ada cepat diperbaiki

5. Successfull Call Ratio(SCR) yang tinggi

\section{Pengukuran Kepuasan Pelanggan}

Kotler dalam Kasmir,

Pengukuran kepuasan pelanggan dapat dilakukan melalui empat sarana, yaitu:

1. Sistem keluhan usulan

Artinya seberapa banyak keluhan atau komplain yang dilakukan pelanggan atau nasabah dalam suatu periode, makan banyak berarti makin kurang baik demikian pula sebaliknya. Untuk itu, perlu adanya sistem keluhan dan usulan, di mana pelanggan mengisi formulir keluhan dan memasukkan ke dalam kotak saran yang telah disediakan. Manajemen elalui karyawan atau pengawasan dapat juga mencatat setiap keluhan yang dilontarkan oleh pelanggan dalam suatu periode tertentu.

2. Survei Kepuasan konsumen

Survei kepuasan konsumen merupakan kegiatan untuk mengetahui bagaimana tingkat kepuasan pelanggan dalam suatu periode. Dalam hal ini manajemen secara berkala perlu melakukan survei kepada pelanggan, baik melalui wawancara maupun kuesioner tentang segala sesuatu yang berhubungan dengan pelayanan tempat pelanggan melakukan transaksi selama ini. Dengan adanya survei ini akan diketahui tingkat kepuasan pelanggan, di mana titik lemah atau kekurangannya.

3. Konsumen samaran

Konsumen samaran merupakan karyawan perusahaan atau pelanggan yang ditugaskan untuk menyamar guna memperoleh informasi tentang perusahaan pesaing. Dalam kasus ini manajemen dapat mengirim karyawannya atau melalui orang lain untuk berpura-pura menjadi pelanggan atau nasabah guna melihat pelayanan yang diberikan oleh karyawannya secara langsung, sehingga terlihat jelas bagaimana cara karyawan melayani pelanggan sesungguhnya. Penyamaran ini untuk melihat secara nyata kualitas pelayanan yang diberikan dan sebaiknya dilakukan beberapa kali dengan kasus yang berbeda.

4. Analisis mantan pelanggan

Artinya cara seperti ini dapat dilakukan dengan melihat catatan pelanggan atau nasabah yang pernah menjadi pelanggan tetapi sekarang tidak lagi (ke luar atau tidak pernah membeli lagi). Cara seperti ini sangat berguna untuk mengetahui sebab-sebab mengapa mereka tidak lagi menjadi pelanggan kita. Usahakan menanyakan alasan mereka tidak datang atau tidak pernah membeli atau menggunakan produk kita. Analisis pelanggan ini sangat penting mengingat yang ditanyakan adalah mereka yang sudah pernah menjadi pelanggan, apalagi yang dulunya pelanggan loyal.

Richard dalam Kasmir, (2017:243) Untuk melakukan pengukuran kepuasan pelanggan dapat dilakukan dengan cara:

1. Mempelajari Persepsi pelanggan terhadap jasa yang ditawarkan

Artinya karyawan dapat melakukan dengan cara wawancara atau kuesioner tentang persepsi atas layanan yang diberikan. Melalui persepsi pelanggan-pelanggan akan tahu apa yang dipikirkan oleh pelanggan atas layanan yang diinginkannya.

2. Menentukan kebutuhan, keinginan, persyaratan dan harapan pelanggan

Karyawan dalam hal ini juga dapat mengidentifikasikan kebutuhan dan keinginan pelanggan yang datang ke perusahaan. Kemudian juga dapat mengidentifikasikan apa yang diharapkan oleh pelanggan, termasuk persyaratan yang mereka inginkan. Dengan demikian, manajemen dapat manambah atau mengurangi sesuai dengan kebutuhan, keinginan dan harapan pelanggan. 
3. Menutup segala kesenjangan yang ada

Artinya untuk menilai kesenjangan apa yang diberikan perusahaan dengan apa yang dibutuhkan dan diinginkan pelanggan. Kesenjangan ini harus di atas sesegera mungkin, sehingga kepuasan pelanggan dapat ditingkatkan.

4. Memeriksa apakah peningkatan mutu pelayanan dan kepuasan pelanggan sesuai harapan atau tidak Artinya secara berkala harus dilakukan penilaian terhadap seluruh layanan yang diberikan kepada pelanggan, sehingga akan ditemukan segala kekurangannya.

5. Dengan mengukur peningkatan kinerja apakah membawa peningkatan laba Artinya suatu ukuran yang dilihat dari keuntungan yang diperoleh pelanggan dalam suatu periode tertentu. Jika keuntungan perusahaan meningkat, maka dapat dikatakan kemungkinan layanan yang diberikan selama ini berjalan baik, demikian juga sebalikya.

6. Memelajari bagaimana akan melakukan sesuatu dan apa yang harus dilakukan kemudian Artinya manajemen terus memantau aktifitas pelayanan yang diberikan setiap hari melalui karyawan atau pengawas. Dari pemantauan ini akan terlihat kejanggalan atau kekurangan yang ada. Kemudian hasil pemantauan ini dapat dijadikan sebagai alat koreksi dan perbaikan ke depan tentang kekurangan pelanggan yang diberikan.

7. Menerapkan proses perbaikan yang berkesinambungan secara terus-menerus Artinya secara terus menerus manajemen harus memperbaiki setiap kekurangan yang ada. Perbaikan terhadap proses yang berkelanjutan akan memberikan hasil yang maksimal. Dapat dipastikan bahwa jika perusahaan terlambat melakukan perbaikan, maka kemungkinan kehilangan pelanggan makin cepat.

\section{METODOLOGI PENELITIAN}

Metode penelitian yang digunakan dalam penelitian ini adalah metode penelitian kuantitatif (positivis). Dalam penelitian ini menggunakan beberapa metode penelitian untuk mendapatkan data sebagai objek penulisan. Adapun metode penelitian yang digunakan adalah:

\section{Jenis Data}

\section{Data Primer}

a. Metode Wawancara

Metode wawancara yaitu teknik pengumpulan data dengan mengajukan pertanyaan kepada pihak-pihak yang berhubungan dengan masalah yang diteliti, guna mendapatkan data-data yang diperlukan.

b. Metode Kuesioner

Metode kuesioner yaitu dengan membuat daftar pertanyaan terlebih dahulu untuk mendapatkan jawaban secara tertulis dari beberapa karyawan yang mewakili objek penelitian, dengan cara mengajukan pertanyaan-pertanyaaan (pertanyaan yang sudah disiapkan secara tertulis dengan alternatif jawaban yang telah disediakan).

2. Data Sekunder atau Studi Kepustakaan

Data sekunder yaitu data yang diperoleh atau dikumpulkan dari sumber-sumber yang ada. Data ini diperoleh dari buku-buku atau laporanlaporan terdahulu yang berkaitan dengan disiplin kerja dan kinerja karyawan.

\section{Populasi dan Sampel}

Pada penelitian yang dilakukan penulis pada bulan Mei 2019 sampai dengan bulan Juni 2019 selama dua bulan, dengan pengambilan data yang digunakan penulis selama Tahun Akademik dari tahun 2016/2017- 2017/2018 penulis menggunakan metode pengambilan secara acak (simple random sampling) yang dimana seluruh anggota populasi mempunyai kesempatan yang sama untuk dipilih. Dalam penelitian ini penulis mendapatkan tentang pengaruh kualitas pelayanan dan Kepuasan Mahasiswa pada Fakultas Keguruan dan Ilmu Pendidikan Universitas Islam As-syafi'iyah yang di berikan kepada mahasiswa sebanyak 40 orang. Jumlah tersebut akan dijadikan sebagai populasi dalam penelitian ini.

1. Uji Validitas

Uji validitas adalah uji yang digunakan untuk menunjukkan sejauh mana alat ukur yang digunakan dalam suatu mengukur apa yang diukur. Uji validitas digunakan untuk mengukur sah, atau valid tidaknya suatu kuesioner. Suatu kuesioner dikatakan valid jika pertanyaan pada kuesioner mampu untuk mengungkapkan sesuatu yang akan diukur oleh kuesioner tersebut.

\section{Uji Reliabilitas}

Reliabilitas, atau keandalan, adalah konsistensi dari serangkaian pengukuran atau serangkaian alat ukur. Hal tersebut bisa berupa pengukuran dari alat ukur yang sama (tes dengan tes ulang) akan memberikan hasil yang sama, atau untuk pengukuran yang lebih subjektif, apakah dua orang penilai memberikan skor yang mirip (reliabilitas antar penilai). Reliabilitas tidak 
sama dengan validitas. Artinya pengukuran yang dapat diandalkan akan mengukur secara konsisten, tapi belum tentu mengukur apa yang seharusnya diukur.

3. Uji Koefisien Korelasi

Koefisien korelasi adalah nilai yang menunjukan kuat / tidaknya hubungan linier antar dua variabel. Koefisien korelasi biasa dilambangkan dengan huruf $r$ dimana nilai $r$ dapat bervariasi dari -1 sampai +1 . Nilai $r$ yang mendekati -1 atau +1 menunjukan hubungan yang kuat antara dua variabel tersebut dan nilai $r$ yang mendekati 0 mengindikasikan lemahnya hubungan antara dua variabel tersebut. Sedangkan tanda + (positif) dan - (negatif) memberikan informasi mengenai arah hubungan antara dua variabel tersebut. Jika bernilai + (positif) maka kedua variabel tersebut memiliki hubungan yang searah. Dalam arti lain peningkatan $\mathrm{X}$ akan bersamaan dengan peningkatan $\mathrm{Y}$ dan begitu juga sebaliknya. Jika bernilai - (negatif) artinya korelasi antara kedua variabel tersebut bersifat berlawanan. Peningkatan nilai $\mathrm{X}$ akan dibarengi dengan penurunan Y. Koefisien korelasi pearson atau Product Moment Coefficient of Correlation adalah nilai yang menunjukan keeratan hubungan linier dua variabel dengan skala data interval atau rasio.

4. Uji Koefisien Determinasi

Koefisien determinasi pada regresi linear sering diartikan sebagai seberapa besar kemampuan semua variabel bebas dalam menjelaskan varians dari variabel terikatnya. Secara sederhana koefisien determinasi dihitung dengan mengkuadratkan Koefisien Korelasi (R).

5. Uji Persamaan Regresi

Uji Persamaan Regresi merupakan suatu alat ukur yang digunakan untuk mengukur ada atau tidaknya korelasi antar variabel.

\section{HASIL PENELITIAN DAN PEMBAHASAN}

\section{Analisis Kualitas Pelayanan dan Kepuasan Mahasiswa}

\section{Uji Validitas}

Pengujian dilakukan dengan membandingkan $r$ hitung dengan $r$ tabel. Nilai $r$ hitung merupakan hasil kolerasi jawaban responden pada masingmasing pernyataan di setiap variabel yang dianalisis dengan program SPSS dengan metode korelasi pearson. Nilai $r$ tabel dapat dilihat pada table $r$ dengan taraf signifikan 5\% atau setara dengan 0,05 dengan derajat kebebasan $\mathrm{df}=\mathrm{n}-2$ atau $40-2=38$ sebesar 0,2638 Lihat pada lampiran $r$ tabel).

Berikut ini adalah data Hasil validitas melalui program SPSS dapat dilihat dalam tabel berikut.

Tabel 4.1

Validitas Variabel X

\begin{tabular}{|c|r|r|r|}
\hline & $\begin{array}{c}\text { Corrected } \\
\text { Item-Total } \\
\text { Correlation } \\
\text { ( } \mathrm{r} \text { hitung) }\end{array}$ & \multicolumn{1}{|c|}{$\mathrm{r}$ table } & Keterangan \\
\hline $\mathrm{X} 1$ & .469 & .2638 & VALID \\
\hline $\mathrm{X} 2$ & .530 & .2638 & VALID \\
\hline $\mathrm{X} 3$ & .422 & .2638 & VALID \\
\hline $\mathrm{X} 4$ & .504 & .2638 & VALID \\
\hline $\mathrm{X} 5$ & .719 & .2638 & VALID \\
\hline $\mathrm{X} 6$ & .587 & .2638 & VALID \\
\hline $\mathrm{X} 7$ & .473 & .2638 & VALID \\
\hline $\mathrm{X} 8$ & .415 & .2638 & VALID \\
\hline $\mathrm{X} 9$ & .375 & .2638 & VALID \\
\hline $\mathrm{X} 10$ & .692 & .2638 & VALID \\
\hline
\end{tabular}

Berdasarkan Tabel diatas terdapat $r$ hitung $>$ $r$ tabel $(0,2638)$ dan valid semua penelitian bisa dilanjutkan.

Tabel 4.2

Validitas Variabel Y

\begin{tabular}{|l|r|r|r|}
\hline & $\begin{array}{c}\text { Corrected } \\
\text { Item-Total } \\
\text { Correlation } \\
\text { ( } \mathrm{r} \text { hitung) }\end{array}$ & \multicolumn{1}{|c|}{ r table } & Keterangan \\
\hline Y1 & .435 & .2638 & VALID \\
\hline Y2 & .294 & .2638 & VALID \\
\hline Y3 & .508 & .2638 & VALID \\
\hline Y4 & .413 & .2638 & VALID \\
\hline Y5 & .602 & .2638 & VALID \\
\hline Y6 & .344 & .2638 & VALID \\
\hline Y7 & .453 & .2638 & VALID \\
\hline Y8 & .530 & .2638 & VALID \\
\hline Y9 & .483 & .2638 & VALID \\
\hline Y10 & .336 & .2638 & VALID \\
\hline
\end{tabular}

Sumber: Perhitungan SPSS 22, 2019

Dilihat dari tabel diatas kesimpulannya semua data valid. Berdasarkan hasil perhitungan pada tabel diatas dapat disimpulkan bahwa semua item pernyataan yang terdapat dalam kuesioner penelitian Kualitas Pelayanan dan Kepuasan Mahasiswa pada Fakultas Keguruan dan Ilmu 
Pendidikan Universitas Islam As-syafi'iyah adalah valid, sesuai dengan kriteria uji validitas $r$ hitung lebih besar dari 0,2638.

\section{Uji Reliabilitas}

Uji Reliabilitas dilakukan menggunakan Cronbach Alpha.Untuk menentukan reliabel atau tidaknya instrument dapat diinterpretasikan dengan batasan yang lebih dari 0,6 adalah cukup reliabel, sedangkan batasan 0,8 adalah reliable dan diatas 0,8 adalah sangat reliable.

Berikut ini adalah data Hasil perhitungan reliabiablitas dapat dilihat dalam tabel berikut.

Reliabilitas Variabel X

Tabel 4.3

Reliability Statistics

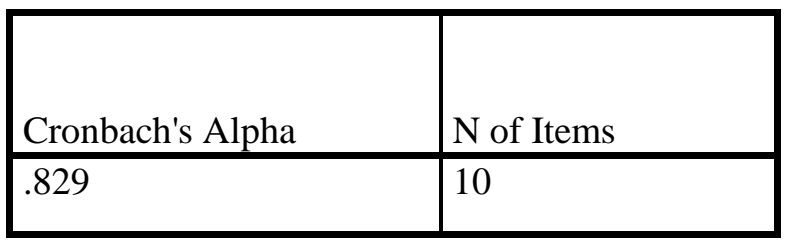

Sumber: Perhitungan SPSS 22, 2019

Reliabilitas Variabel Y

Tabel 4.4

Reliability Statistics

\begin{tabular}{|l|l|}
\hline & \\
Cronbach's Alpha & N of Items \\
\hline .772 & 10 \\
\hline
\end{tabular}

Sumber: Perhitungan SPSS 22, 2019

Tabel 4.5

Hasil Reliabilitas

\begin{tabular}{|l|l|l|}
\hline Variabel & Cronbach's alpha & Keterangan \\
\hline $\begin{array}{l}\text { Kualitas } \\
\text { Pelayanan (X) }\end{array}$ & 0,829 & $\begin{array}{l}\text { Sangat } \\
\text { Reliabel }\end{array}$ \\
\hline $\begin{array}{l}\text { Kepuasan } \\
\text { Pelanggan(Y) }\end{array}$ & 0,722 & $\begin{array}{l}\text { Sangat } \\
\text { Reliabel }\end{array}$ \\
\hline
\end{tabular}

Sumber: Perhitungan SPSS 22, 2019

Berdasarkan hasil perhitungan SPSS pada tabel diatas dapat dinyatakan bahwa koefisien reliabilitas variabel Kualitas Pelayanan $(X)=0,829$ dan variabel Kepuasan Mahasiswa $(\mathrm{Y})=0,722$ lebih. Sehingga dapat disimpulkan seluruh butir pertanyaan Kualitas Pelayanan dan Kepuasan Pelanggan adalah sangat reliabel.

3. Uji Koefisien Korelasi

Analisis ini digunakan untuk mengetahui seberapa besar hubungan dan interprestasi antara variabel kualitas pelayanan (variabel $\mathrm{X}$ ) terhadap variabel kepuasan mahasiswa (variabel Y) pada Fakultas Keguruan dan Ilmu Pendidikan Universitas Islam As-syafi'iyah yang dilihat dari hasil perhitungan menggunakan Program SPPS 22.

Berikut ini adalah data Hasil perhitungan menggunakan Program SPPS 22 dapat dilihat dalam tabel berikut.

Tabel 4.6

Koefisien Korelasi Correlations

\begin{tabular}{|ll|l|l|}
\hline & & Pelayanan & Kepuasan \\
\hline Pelayanan & $\begin{array}{l}\text { Pearson } \\
\text { Correlation } \\
\text { Sig. } \\
\text { tailed) } \\
\mathrm{N}\end{array}$ & 1 & $.896^{* * *}$ \\
\hline Kepuasan & $\begin{array}{l}\text { Pearson } \\
\text { Correlation } \\
\text { Sig. } \\
\text { tailed } \quad(2-\end{array}$ & .000 & .000 \\
$\mathrm{~N}$ & 40 & 40 \\
\hline
\end{tabular}

**. Correlation is significant at the 0.01 level (2tailed).

Sumber: Perhitungan SPSS 22, 2019

Dari hasil perhitungan di atas dapat diketahui terdapat hubungan antara kualitas pelayanan dan kepuasan mahasiswa sebesar 0, 896. Mengacu pada tabel Hasil Koefisien Kolerasi hasil koefisien kolerasi antara 0,801,000 (tabel Skala Likert) masuk kategori "Sangat Puas" yang berarti bahwa ada pengaruh yang sangat kuat antara kualitas pelayanan dengan kepuasan mahasiswa pada Fakultas Keguruan dan Ilmu Pendidikan Universitas Islam As-syafi'iyah Jakarta dan searah karena bernilai positif dan mendekati angka satu. Artinya apabila kualitas pelayanan mereka ditingkatkan maka kepuasan mahasiswa akan meningkat dan sebaliknya jika kualitas pelayanan yang sudah diterapkan tidak dilakukan maka kepuasan mahasiswa akan menurun, sedangkan untuk nilai signifikan dapat dilihat dari nilai Sig (2-tailed) sebesar 0,000 yang mana nilainya lebih kecil dari 0,05 maka dapat diartikan bahwa kedua variabel tersebut memiliki hubungan yang signifikan. 


\section{Uji Koefisien Determinasi}

Hasil dari data kuesioner yang telah diolah untuk diuji hubungan antaradua variable, yaitu variable kualitas pelayanan terhadap variable keputusan konsumen. Pengolahan data kuesioner ini diolah menggunakan program aplikasi SPSS 22 dan dengan analisis regresi linear. Berikut adalah hasil perhitungannya Berikut ini adalah data hasil Kofisien Determinasi menggunakan Program SPSS 22 dapat dilihat dalam table berikut:

Tabel 4.7

\section{Model Summary}

\begin{tabular}{|l|l|l|l|l|}
\hline Model & $\mathrm{R}$ & $\begin{array}{l}\mathrm{R} \\
\text { Square }\end{array}$ & $\begin{array}{l}\text { Adjusted } \\
\text { R Square }\end{array}$ & $\begin{array}{l}\text { Std. Error } \\
\text { of the } \\
\text { Estimate }\end{array}$ \\
\hline 1 & $.896^{\mathrm{a}}$ & .804 & .798 & 1.254 \\
\hline
\end{tabular}

a. Predictors: (Constant), PELAYANAN

Koefisien determinasinya (R Square) adalah sebesar 0,804 yang artinya adalah kualitas pelayanan berpengaruh sebesar $80,4 \%$ terhadap kepuasan sisanya sebesar $19,6 \%$ dipengaruhi faktor lain yang diteliti sebutkan contohnya fasilitas dan lain - lain.

5. Uji Persamaan Regresi

Uji persamaan regresi ini Digunakan untuk memprediksi pengaruh antar variable $\mathrm{X}$ (kualitas pelayanan) terhadap variable $\mathrm{Y}$ (kepuasan mahasiswa) pada Fakultas Keguruan dan Ilmu Pendidikan Universitas Islam As-syafi'iyah Jakarta.

Maka hasil regresi nya dapat dilihat pada kolam sebagai berikut:

Tabel.4.8

Coefficients $^{\mathrm{a}}$

\begin{tabular}{|l|l|l|l|l|l|}
\hline & $\begin{array}{l}\text { Unstandard } \\
\text { ized } \\
\text { Coefficient } \\
\text { s }\end{array}$ & $\begin{array}{l}\text { Standardi } \\
\text { zed } \\
\text { Coefficie } \\
\text { nts }\end{array}$ & & \\
\cline { 2 - 5 } Model & B & $\begin{array}{l}\text { Std. } \\
\text { Err } \\
\text { or }\end{array}$ & Beta & T & $\begin{array}{l}\text { Si } \\
\text { g. }\end{array}$ \\
\hline 1 (Constant) & 4.495 & $\begin{array}{l}3.1 \\
10\end{array}$ & & $\begin{array}{l}1.44 \\
5\end{array}$ & $\begin{array}{l}.15 \\
7 \\
\text { PELAYAN }\end{array}$ \\
AN & .932 & .07 & .896 & 12.4 & .00 \\
VARIABE & & 5 & & 70 & 0 \\
L (X) & & & & & \\
\hline
\end{tabular}

a.Dependent Variable : Kepuasan

Sumber: Perhitungan SPSS 22, 2019

Berdasarkan Tabel Coefficients dapat diketahui bahwa nilai Sig. (2-tailed) senilai $0,000<0,05$ maka keputusan diterima, dapat disimpulkan bahwa terdapat persamaan yang signifikan antara kualitas pelayanan dan kepuasan mahasiswa di Fakultas Keguruan dan Ilmu Pendidikan Universitas Islam As-syafi' iyah Jakarta. Bedasarkan table perhitungan SPSS 23 di atas, dapat diperoleh persamaan yaitu:

$$
\begin{aligned}
& \mathbf{Y}=\mathbf{a}+\mathbf{b x} \\
& a=4,495 \mathrm{Y} \\
& \mathrm{b}=\mathbf{0 , 9 3 2} \mathrm{X}
\end{aligned}
$$

Dimana :

$\mathrm{Y}=$ Kepuasan Pelanggan

$\mathrm{X}=$ Kualiatas Pelayanan

\begin{tabular}{|c|c|c|c|c|c|}
\hline No & $\mathrm{X}$ & Y prediksi & No & $\mathrm{Y}$ & $\mathrm{X}$ prediksi \\
\hline 1 & 36 & 38 & 1 & 44 & 45 \\
\hline 2 & 44 & 46 & 2 & 36 & 38 \\
\hline 3 & 42 & 44 & 3 & 36 & 38 \\
\hline 4 & 38 & 40 & 4 & 36 & 38 \\
\hline 5 & 36 & 38 & 5 & 36 & 38 \\
\hline 6 & 39 & 40 & 6 & 41 & 42 \\
\hline 7 & 37 & 38 & 7 & 47 & 48 \\
\hline 8 & 41 & 42 & 8 & 48 & 49 \\
\hline 9 & 42 & 50 & 9 & 36 & 38 \\
\hline 10 & 42 & 50 & 10 & 36 & 38 \\
\hline 11 & 43 & 44 & 11 & 38 & 40 \\
\hline 12 & 35 & 38 & 12 & 39 & 40 \\
\hline 13 & 33 & 36 & 13 & 30 & 32 \\
\hline 14 & 39 & 40 & 14 & 30 & 32 \\
\hline 15 & 38 & 40 & 15 & 38 & 40 \\
\hline 16 & 34 & 36 & 16 & 39 & 40 \\
\hline 17 & 50 & 51 & 17 & 42 & 43 \\
\hline 18 & 40 & 41 & 18 & 31 & 33 \\
\hline 19 & 38 & 40 & 19 & 33 & 35 \\
\hline 20 & 38 & 40 & 20 & 48 & 49 \\
\hline 21 & 43 & 44 & 21 & 38 & 40 \\
\hline 22 & 34 & 36 & 22 & 38 & 40 \\
\hline 23 & 37 & 38 & 23 & 34 & 36 \\
\hline 24 & 42 & 50 & 24 & 42 & 43 \\
\hline 25 & 40 & 41 & 25 & 35 & 37 \\
\hline 26 & 39 & 40 & 26 & 39 & 40 \\
\hline 27 & 33 & 36 & 27 & 40 & 41 \\
\hline 28 & 38 & 40 & 28 & 32 & 34 \\
\hline 29 & 33 & 36 & 29 & 31 & 33 \\
\hline 30 & 34 & 36 & 30 & 41 & 42 \\
\hline 31 & 32 & 34 & 31 & 46 & 47 \\
\hline 32 & 38 & 40 & 32 & 35 & 37 \\
\hline 33 & 38 & 40 & 33 & 43 & 44 \\
\hline 34 & 44 & 46 & 34 & 39 & 40 \\
\hline 35 & 42 & 50 & 35 & 37 & 38 \\
\hline 36 & 26 & 28 & 36 & 35 & 37 \\
\hline 37 & 24 & 26 & 37 & 36 & 38 \\
\hline 38 & 23 & 25 & 38 & 46 & 47 \\
\hline 39 & 24 & 26 & 39 & 47 & 48 \\
\hline 40 & 42 & 50 & 40 & 40 & 41 \\
\hline
\end{tabular}

Hal ini menunjukkan bahwa :

Tabel 4.9.

Konstan (a) $=4,495$ menyatakan bahwa jika tidak ada kualitas pelayanan yang dilakukan di Fakultas Keguruan dan Ilmu Pendidikan, maka kepuasan pelanggan sebesar 4,495. 
koefisien regresi $(b)=0,932$ menyatakan bahwa setiap penambahan satu kualitas pelayanan, maka kepuasan pelayanan akan meningkat sebesar 0,932. Dan sebaliknya jadi arah hubungan kualitas pelayanan dengan kepuasan mahasiswa Fakultas Keguruan dan Ilmu Pendidikan Universitas Islam As-syafi'iyah adalah positif dan searah.

\section{KESIMPULAN DAN SARAN}

\section{Kesimpulan}

Berdasarkan hasil penelitian dan pembahasan mengenai Pengaruh Kualitas Pelayanan Akademik Terhadap Kepuasan Mahasiswa Pada Fakultas Keguruan dan Ilmu Pendidikan Universitas Islam As-Syafi'iyah Jakarta, melalui riset, wawancara, dan penyebaran kuesioner terhadap pelanggan, maka penulis menarik kesimpulan sebagai berikut:

1. Pengaruh variable pengaruh kualitas pelayanan akademik terhadap kepuasan mahasiswa dapat di buktikan dari hasil koefisien korelasi dengan nilai $\mathrm{r}=0,896$ artinya menunjukan hubungan sangat kuat antara Pengaruh Kualitas Pelayanan Akademik Terhadap Kepuasan Mahasiswa Pada Fakultas Keguruan dan Ilmu Pendidikan Universitas Islam As-Syafi'iyah Jakarta.

2. Berdasarkan perhitungan koefisien determinasi diperoleh sebesar $804 \%$ menunjukan benarnya pengaruh kualitas pelayanan akademik terhadap kepuasan mahasiswa dan sisanya sebesar 19,6\% dipengaruhi faktor lain yang diteliti yaitu fasilitas, kinerja (performance) karakteristik operasi pokok dari produk inti (core product) yang dibeli, keistimewaan tambahan (features), keandalan (reliability), kesesuaian dengan spesifikasi (conformace to specification), daya tahan (durability), serviceability, estetika dan kualitas yang dipersepsikan (perceived quality).

3. Berdasarkan perhitungan koefisien regresi di proleh persamaan $\mathrm{Y}=4,495+0,932 \mathrm{X}$ menunjukan tanpa variable kualitas pelayanan akademik maka nilai kualitas pelayanan sebesar 4,495 setiap nilai X kualitas pelayanan dinaikan atau turunkan satu angka maka akan menaikan atau menurunkan $\mathrm{Y}$ (kepuasan mahasiswa) sebesar 0,932 .

\section{Saran}

Berdasarkan kesimpulan yang diperoleh mengenai Pengaruh Kualitas Pelayanan Akademik Terhadap Kepuasan Mahasiswa Pada Fakultas Keguruan dan Ilmu Pendidikan Universitas Islam As-Syafi'iyah Jakarta, peneliti mencoba memberikan saran yang diharapkan dapat bermanfaat dan dapat dijadikan sebagai bahan pertimbangan bagi perusahaan maupun peneliti lainnya, adapun saran yang hendak disampaikan, diantaranya:

1. Fakultas Keguruan dan Ilmu Pendidikan Universitas Islam As-Syafi'iyah Jakarta sebaiknya meningkatkan kualitas pelayanan dengan baik, untuk memberikan penilaian atas kepuasan yang dirasakan mahasiswa dengan cara menekan pernyataan puas atau tidak terhadap tampilan pelayanan kepada mahasiswa FKIP UIA untuk dijadikan bahan evaluasi seluruh FKIP UIA untuk menjadi lebih baik.

2. Fakultas Keguruan dan Ilmu Pendidikan Universitas Islam As-Syafi'iyah perlu meningkatkan kualitas dari fasilitas yang disediakan untuk menciptakan kenyamanan bagi mahasiswa.

\section{DAFTAR PUSTAKA}

Adil, A., Syamsun, M., \& Najib, M. (2017). Pengaruh Kualitas Pelayanan dan Biaya terhadap Kepuasan dan Loyalitas Pasien RSUD Kota Bogor. Jurnal Aplikasi Manajemen. https://doi.org/10.18202/jam23026332.14.3.0 4

Ariani, W. (2016). Manajemen Kualitas. Jurnal Managemen.

Fikri, S., Wiyani, W. dan, \& Suwandaru, A. (2016). PENGARUH KUALITAS PELAYANAN TERHADAP KEPUASAN DAN LOYALITAS MAHASISWA (Studi pada Mahasiswa Strata I Fakultas Ilmu Sosial dan Ilmu PolitikUniversitas Merdeka Malang) Sirhan Fikri, Wahyu Wiyani, Agung Suwandaru. Jurnal Bisnis Dan Manajemen, Januari 2016.

Freddy Rangkuti. (2016). Customer Care Excellence: Meningkatkan Kinerja Perusahaan Melalui Pelayanan Prima.

Kasmir. (2017). Customer Services Excellent (Cetakan 1). Jakarta: Rajawali pers.

Mardo. (2016). Manajemen Pemasaran Jasa (Cetakan 1; Sartono, ed.). Yogyakarta: deepublish.

Nurhidayati, N., \& Yuliantari, K. (2018). Analisis Pengaruh Kepuasan Pelanggan Terhadap Loyalitas Pelanggan pada Fish Streat Cabang Tebet. Widya Cipta - Jurnal Sekretari Dan Manajemen, 2(1), 69-75. 
Richard F.Gerson. (2018). Mengukur Kepuasan Pelanggan (measuring customer statisfaction).

Riyanto, A. (2018). Implikasi Kualitas Pelayanan Dalam Meningkatkan Kepuasan Pelanggan Pada PDAM Cibadak Sukabumi. Implikasi Kualitas Pelayanan Dalam Meningkatkan Kepuasan Pelanggan Pada PDAM Cibadak Sukabumi.

Sediawan, R. (2015). ANALISIS DALAM MENCIPTAKAN KUALITAS PELAYANAN UNTUK MENGARAH PADA KEPUASAN KONSUMEN. ANALISIS DALAM MENCIPTAKAN KUALITAS PELAYANAN UNTUK MENGARAH PADA KEPUASAN KONSUMEN.

Setyabudi, D. dan I. (2014). onsumen dan Pelayanan Prima.
Sugeng, I. S., \& Rafik, A. (2018). Pengaruh Kualitas Pelayanan Terhadap Kepuasan Masyarakat Pada Bagian Pelayanan Pembuatan Kartu Tanda Penduduk Elektronik ( E-Ktp ) Pada Kantor Kelurahan Duren Sawit Jakarta Timur. Pengaruh Kualitas Pelayanan Terhadap Kepuasan Masyarakat Pada Bagian Pelayanan Pembuatan Kartu Tanda Penduduk Elektronik ( E-Ktp ) Pada Kantor Kelurahan Duren Sawit Jakarta Timur.

Suryati. (2015). No TitleManajmen Pemasaran (Cetakan 1; Suryati, ed.). Yogyakarta: deepublish.

Wijaya. (2018). Manajemen kualitas jasa (Cetakan 1; Sarwiji, ed.). Jakarta: indeks-penerbit. Windasuri, H. (2017). Excellent Service. 